\title{
Glomerulonephritis and immunosuppression associated with dietary essential fatty acid deficiency in gilthead sea bream, Sparus aurata L., juveniles
}

\author{
D Montero', J Socorro', L Tort ${ }^{2}$, M J Caballero', L E Robaina ${ }^{1}$, \\ J M Vergara ${ }^{1}$ and M S Izquierdo' \\ 1 Grupo de Investigación en Acuicultura (GIA), Telde, Las Palmas, Canary Islands, Spain \\ 2 Departamento de Biologia Celular i Fisiologia, Facultad de Ciencias, Universitat Autónoma de Barcelona, Spain
}

\begin{abstract}
An experiment was conducted to determine the effect of an essential fatty acid (EFA) deficient diet on growth, immune status and renal morphology of juvenile gilthead sea bream, using two diets: a control diet containing $2 \%$ (DW) of $\mathrm{n}-3$ high unsaturated fatty acid (n-3 HUFA) and a diet formulated to be deficient in EFA for this species and containing $0.5 \%$ DW of n-3 HUFA (diet NFA). After 9 weeks of feeding the EFA-deficient diet fish showed a reduction in growth compared with the control group $(107.48 \pm 9.14$ and $123.14 \pm$ $11.87 \mathrm{~g}$ final weight respectively). Fish fed the NFA diet showed a reduction in the erythrocyte volume together with increased erythrocyte fragility, haemoglobin content and red blood cell count in comparison with fish fed the control diet. EFA deficiency also reduced cellular immunity in terms of neutrophil activity and the number of circulating lymphocytes. The serum alternative complement pathway was markedly reduced in fish fed the EFA deficient diet. Fish fed the control diet showed glomeruli with a well-defined Bowman's space and normal renal tubes. However, up to $88 \%$ of fish fed the EFA-deficient diet showed alterations in renal morphology affecting at least $50 \%$ of the glomeruli, which showed extreme dilation of capillaries and occlusion of Bowsman's capsule. Mesangial proliferation and diffuse thickening of the capillary
\end{abstract}

Correspondence $D$ Montero, Grupo de Investigación en Acuicultura (GIA), PO Box 56, 35200, Telde, Las Palmas, Canary Islands, Spain

(dmontero@iccm.rcanaria.es) walls, as well as renal tube degeneration, were also observed.

Keywords: complement, docosahexaenoic acid, eicosapentaenoic acid, gilthead sea bream, glomerulonephritis, n-3 high unsaturated fatty acid.

\section{Introduction}

Besides being an excellent energy source and a vehicle for fat-soluble vitamins in marine fish, dietary lipids provide the necessary essential fatty acids (EFAs) to regulate membrane functioning of different tissues and the synthesis of different types of eicosanoids and physiologically active molecules. Marine fish have a very limited gene expression of delta 6 and delta 5 activity and thus are not able to synthesize polyunsaturated fatty acids (PUFAs) (Mourente \& Tocher 1993). Consequently n-3 fatty acids of more than 20 carbons ( $n-3$ high unsaturated fatty acids or n-3 HUFAs) are essential for marine fish for growth and other physiological events, including the immune function. The role of dietary lipids in fish immunity is not well understood (Lall 2000). At the least, dietary lipids modulate the immune response by influencing the physical properties of immune cell membranes and membrane-associated enzymes and receptor sites. Some studies provide good evidence of the effect of dietary fatty acid imbalances on different mechanisms of the immune system of cultured fish. For instance, Sheldon \& Blazer (1991) found an enhanced bactericidal activity of channel catfish, Ictalurus punctatus (Rafinesque), macrophages when fish were fed diets rich in n-3 fatty acids. Similar 
results were obtained by Kiron, Fukuda, Takeuchi \& Watanabe (1995) with rainbow trout, Oncorhynchus mykiss (Walbaum), fed a diet containing $\mathrm{n}-3$ HUFA. They also found that fish fed PUFAs were more resistant to bacterial infections. Ashton, Clemens, Barrow, Secombes \& Rowley (1994) found that leucocytes from rainbow trout fed a diet enriched with n-3 fatty acids had greater migration stimulating ability than those from trout fed $n-6$ fatty acid enriched diet. In gilthead sea bream, Sparus aurata L., it has been found that adequate levels of n-3 HUFA in diets are necessary for the maintenance of alternative complement activity (Montero, Tort, Izquierdo, Robaina \& Vergara 1998). In addition, several types of eicosanoids are well known to regulate immune functions in vertebrates, including fish (Rowley, Knight, LloydEvans, Holland \& Vickers 1995).

An inadequate fatty acid profile in fish diets also seems to affect cell integrity of several tissues. Intestine and liver are among the most readily affected tissues and have been studied by several authors. Robaina, Izquierdo, Moyano, Socorro, Vergara \& Montero (1998) found that an increase in the n-3/n-6 ratio produces a reduction in liver lipid deposits in gilthead sea bream fed a soya bean meal based diet. In some species, liver steatosis was observed when fish were fed a n-3 HUFA-deficient diet (Montero, Robaina, Socorro, Vergara, Tort \& Izquierdo 2001). Alterations in the intestinal mucus of fish fed diets with an unbalanced fatty acid composition have been described for Arctic charr, Salvelinus alpinus (L.) (Olsen, Myklebust, Kaino \& Ringø 1999), rainbow trout (Caballero, Obach, Rosenlund, Montero, Gisvold \& Izquierdo 2002) or gilthead sea bream (Caballero, Izquierdo, Kjorsvik, Montero, Socorro, Fernández \& Rosenlund 2003). Damage in other tissues has been little studied despite the evidence for the protective role of $n-3$ fatty acids in mammalian renal diseases such as murine lupus nephritis (Chandrasekar \& Fernandes 1994) or focal glomerulosclerosis (Goldstein, Wheeler, Sandstrom, Kawachi \& Salant 1995). Montero, Blazer, Socorro, Izquierdo \& Tort (1999) found alterations in macrophage aggregates of both spleen and kidney of gilthead sea bream fed an EFA-deficient diet. However, little is known about the effect of dietary EFA deficiency on kidney morphology.

Thus, the aim of this study was to study the effect of an EFA deficiency on the gilthead sea bream immune system and in particular on kidney morphology.

\section{Material and methods}

\section{Diets}

Two sardine meal based diets were formulated with the same proximal composition (Table 1). The control diet (diet C) was based on fish oil and was formulated to cover the n-3 HUFA requirements for this species whereas diet NFA was formulated to be deficient in n-3 HUFA (Montero, Tort, Izquierdo, Socorro, Robaina, Vergara \& FernándezPalacios 1996) (Table 2) so as to induce the effects of dietary EFA deficiency in marine fish as described by Watanabe (1982), including those related to fish growth, survival and fatty acid utilization.

\section{Experimental procedures}

The experiment was carried out at the Instituto Canario de Ciencias Marinas (Canary Islands, Spain). Thirty-six gilthead sea bream ( $55 \mathrm{~g}$ mean weight), supplied by a local farm (ADSA, San Bartolomé de Tirajana, Canary Islands, Spain), were randomly distributed among six 100-L circular fibreglass tanks (six fish per tank, each diet fed to three tanks) supplied with continuous sea water $\left(8.3 \mathrm{~L} \mathrm{~min}^{-1}\right)$. Water temperature ranged from 19.0 to $22.4^{\circ} \mathrm{C}$ and aeration (oxygen ranged from 6.7 to $8.3 \mathrm{mg} \mathrm{L}^{-1}$ during the experimental

Table 1 Composition (\%) of experimental diets

\begin{tabular}{lcc}
\hline & \multicolumn{2}{c}{ Diet } \\
\cline { 2 - 3 } Ingredient & \multicolumn{1}{c}{$\mathrm{C}$} & NFA \\
\hline Sardine meal (SM) & 64.0 & 16.0 \\
Oil extracted SM & - & 42.9 \\
Sardine oil & 1.8 & - \\
Beef tallow & 3.4 & 10.3 \\
Starch & 12.0 & 12.0 \\
Dextrin & 4.0 & 4.0 \\
Alpha-cellulose & 10.0 & 10.0 \\
CMC $^{\text {a }}$ & 0.5 & 0.5 \\
Mineral mix & 1.3 & 1.3 \\
Vitamin mix & 2.0 & 2.0 \\
Choline chloride & 0.9 & 0.9 \\
\hline
\end{tabular}

${ }^{a}$ Carboxymethyl cellulose.

b $\left(\mathrm{g} \mathrm{kg}^{-1}\right.$ diet): $\left(\mathrm{H}_{2} \mathrm{PO}_{4}\right) \mathrm{Ca}, 1.605 ; \mathrm{CaCO}_{3}, 4.0 ; \mathrm{FeSO}_{4} \cdot 7 \mathrm{H}_{2} \mathrm{O}, 1.5$; $\mathrm{MgSO}_{4} \cdot 7 \mathrm{H}_{2} \mathrm{O}, 1.605 ; \mathrm{K}_{2} \mathrm{HPO}_{4}, 2.8 ; \mathrm{Na}_{2} \mathrm{PO}_{4}, 1 ; \mathrm{Al}\left(\mathrm{SO}_{4}\right)_{3} \cdot 6 \mathrm{H}_{2} \mathrm{O}, 0.02$; $\mathrm{ZnSO}_{4} \cdot 7 \mathrm{H}_{2} \mathrm{O}, 0.24 ; \mathrm{CuSO}_{4} \cdot 5 \mathrm{H}_{2} \mathrm{O}, 0.12 ; \mathrm{KI}, 0.02 ; \mathrm{CoSO}_{4} \cdot 78 \mathrm{H}_{2} \mathrm{O}$, $0.08 ; \mathrm{MnSO}_{4} \cdot \mathrm{H}_{2} \mathrm{O}, 0.08$.

${ }^{c}\left(\mathrm{mg} \mathrm{kg}^{-1}\right.$ diet): Vitamin A (retinol acetate), 10000 (IU); $\mathrm{D}_{3}, 2000$ (IU); K, 20; E (alpha tocopherol), 150; $\mathrm{B}_{12}, 0.5$; Biotin, $1 ; \mathrm{B}_{6}$, 40; folic acid, 10; $\mathrm{B}_{1}, 40 ; \mathrm{B}_{2}, 50$; pantothenic acid, 117; nicotinic acid, 200; myoinositol, 2000; ascorbic acid, 5000; ethoxyquin, 100. 
Table 2 Main fatty acid composition of the experimental diets (\% DW)

\begin{tabular}{|c|c|c|}
\hline \multirow[b]{2}{*}{ Fatty acid } & \multicolumn{2}{|l|}{ Diet } \\
\hline & $\mathrm{C}$ & NFA \\
\hline $14: 0$ & 0.68 & 0.49 \\
\hline 15:0 & 0.06 & 0.02 \\
\hline $16: 0$ & 3.49 & 4.49 \\
\hline $16: 1 n-7$ & 0.60 & 0.24 \\
\hline $17: 0$ & 0.13 & 0.24 \\
\hline $17: 1$ & 0.11 & 0.06 \\
\hline $16: 4 n-3$ & 0.13 & 0.02 \\
\hline $18: 0$ & 1.99 & 4.61 \\
\hline $18: 1 n-9$ & 1.65 & 3.52 \\
\hline $18: 1 n-7$ & 0.34 & 0.12 \\
\hline $18: 2 n-6$ & 0.19 & 0.33 \\
\hline $18: 3 n-3$ & 0.04 & 0.03 \\
\hline $18: 4 n-3$ & 0.17 & 0.04 \\
\hline $20: 1 n-9$ & - & 0.01 \\
\hline $20: 1 n-7$ & 0.12 & 0.03 \\
\hline $20: 4 n-6$ & 0.07 & 0.02 \\
\hline $20: 5 n-3$ & 0.97 & 0.18 \\
\hline $22: 1 n-11$ & 0.09 & 0.01 \\
\hline $22: 1 n-9$ & 0.03 & 0.01 \\
\hline $22: 3 n-6$ & 0.07 & 0.01 \\
\hline $22: 5 n-6$ & 0.03 & - \\
\hline $22: 5 n-3$ & 0.11 & 0.02 \\
\hline $22: 6 n-3$ & 0.88 & 0.28 \\
\hline Saturated & 6.47 & 9.95 \\
\hline Monoenoics & 3.07 & 4.09 \\
\hline$\Sigma n-3$ & 2.35 & 0.58 \\
\hline$\Sigma n-6$ & 0.53 & 0.38 \\
\hline$\Sigma n-9$ & 1.75 & 3.61 \\
\hline n-3 HUFA & 2.01 & 0.49 \\
\hline EPA/ARA & 13.9 & 9.00 \\
\hline
\end{tabular}

period. Natural light illuminated the tanks at a light cycle close to $12 \mathrm{hL} / 12 \mathrm{hD}$.

Fish were fed twice daily at a feeding rate of $2.5 \%$ fish body weight per day, 6 days per week for 9 weeks. Body weight was measured at the beginning and at the end of the experimental period.

\section{Blood collection and sample preparation}

All fish were individually sampled from each tank. No anaesthetic was used, in order to avoid the effect of anaesthesia on blood parameters. Fish handling time was $<1 \mathrm{~min}$ per fish. Total capture time was $<8$ min per tank in order to minimize capture stress effects on analysed parameters (Sumpter 1997). Blood was obtained by caudal sinus puncture with a 1-mL plastic syringe and two aliquots of blood were used for different analyses. The first aliquot was transferred to an Eppendorf tube coated with lithium heparin as anticoagulant and was used for whole blood determinations [haematology, white blood cell count, erythrocyte fragility and nitro blue tetrazo- lium (NBT) index]. A second aliquot was transferred to another Eppendorf tube without anticoagulant and was used for serum determinations.

\section{Haematology, erythrocyte fragility and NBT index}

Haematocrit $(\mathrm{Ht})$ was measured by microcentrifugation $(3000 \mathrm{~g}, 10 \mathrm{~min})$. Circulating red blood cell number $(\mathrm{RBC})$ and total haemoglobin $(\mathrm{Hb})$ were determined by a System Microcell Counter F-800 (TDA Medical Electronics Co. Ltd, Tokyo, Japan). Mean cellular haemoglobin $(\mathrm{MCH})$, mean cellular volume (MCV) and mean cellular haemoglobin concentration (MCHC) were determined as described by Klontz (1994). A quantity of $50 \mu \mathrm{L}$ of whole blood was fixed in $2.5 \%$ glutaraldehyde, buffered with $1 \mathrm{~nm}$ Tris and diluted in Cortland saline. This suspension was used to determine the circulating neutrophil and lymphocyte number in a Neusbaum haemocytometer. Erythrocyte fragility was determined as spontaneous haemolysis following the method described by Draper \& Csallany (1969), and modified by Cowey, Adron, Murray, Youngson \& Knox (1981) and Wilson, Bowser \& Poe (1984). The reduction of NBT to formazan caused by oxygen radicals from circulating neutrophils was measured spectrophotometrically as described by Siwicki, Anderson \& Antychowitz (1993). NBT index was calculated as the ratio between the NBT activity measured as described above and the number of circulating neutrophils (number of cells per $\mathrm{mm}^{3}$ of blood) counted in the Neusbaum haemocytometer.

\section{Serum determinations}

The second aliquot of blood was allowed to clot at $4{ }^{\circ} \mathrm{C}$ for $2 \mathrm{~h}$. Serum was then separated by centrifugation at $3000 \mathrm{~g}$ for $10 \mathrm{~min}$ and stored at $-80{ }^{\circ} \mathrm{C}$ until analysis. Alternative complement pathway activity using rabbit RBC was determined as described by Sunyer \& Tort (1995) for gilthead sea bream. The reciprocal of the serum dilution causing $50 \%$ lysis of $\mathrm{RBC}$ is designated as the $\mathrm{ACH} 50$ and the results are presented as $\mathrm{ACH} 50$ units $\mathrm{mL}^{-1}$.

\section{Biochemical analysis of the diets}

Total lipid, crude protein, moisture content and fatty acids of diets were determined. Crude protein 
was determined by the Kjeldahl method. Total lipid was extracted with chloroform/methanol $(2: 1 \mathrm{v} / \mathrm{v})$ as described by Folch, Lees \& Sloane-Stanley (1957). Fatty acid methyl esters were obtained by transmethylation as described by Christie (1982) and identified using gas chromatography under conditions previously described (Izquierdo, Watanabe, Takeuchi, Arakawa \& Kitajima 1990).

\section{Histological samples}

At the end of the experiment, kidneys of six fish from each tank were fixed in 10\% neutral-buffered formalin. Samples were stained with haematoxylin and eosin (H \& E) and periodic acid Schiff (PAS) for histological examination (Martoja \& MartojaPierson 1970).

\section{Statistical analysis}

All data were statistically analysed using Student's $t$-test (Sokal \& Rohlf 1995).

\section{Results}

As expected, fish fed the EFA-deficient diet showed lower growth compared with those fed the control diet (Table 3). No mortalities and no infections occurred during the experimental period.

Table 3 Effect of dietary n-3 HUFA deficiency on growth and haematological and immune parameters of gilthead sea bream juveniles

\begin{tabular}{lcc}
\hline & \multicolumn{2}{l}{ Diet } \\
\cline { 2 - 3 } & $\mathrm{C}$ & \multicolumn{1}{c}{ NFA } \\
\hline Initial weight $(\mathrm{g})$ & $55.6 \pm 2.7$ & $54.5 \pm 3.3$ \\
Final weight $(\mathrm{g})$ & $123.1 \pm 11.9^{\mathrm{a}}$ & $107.5 \pm 9.1^{\mathrm{b}}$ \\
Haematocrit $(\%)$ & $37.8 \pm 6.9$ & $35.8 \pm 3.3$ \\
Haemoglobin $\left(\mathrm{g} \mathrm{dL} \mathrm{dL}^{-1}\right)$ & $9.7 \pm 2.0^{\mathrm{a}}$ & $11.3 \pm 3.1^{\mathrm{b}}$ \\
$\mathrm{RBC}\left(\times 10^{6} / \mathrm{mm}^{3}\right)$ & $3.0 \pm 0.6^{\mathrm{a}}$ & $3.6 \pm 1.0^{\mathrm{b}}$ \\
$\mathrm{MCHC}\left(\mathrm{g} \mathrm{dL}^{-1}\right)$ & $26.0 \pm 4.8$ & $32.0 \pm 10.3$ \\
MCV $(\mathrm{fl})$ & $129.3 \pm 29.0^{\mathrm{a}}$ & $105.5 \pm 27.0^{\mathrm{b}}$ \\
MCH $(\mathrm{pg})$ & $32.4 \pm 2.9$ & $31.4 \pm 2.4$ \\
Erythrocyte fragility $(\%)$ & $3.9 \pm 2.4^{\mathrm{a}}$ & $10.4 \pm 14.2^{\mathrm{b}}$ \\
Circulating lymphocytes & $41.2 \pm 9.7^{\mathrm{a}}$ & $33.4 \pm 7.8^{\mathrm{b}}$ \\
$\left(\times 10^{3} \mathrm{~mm}^{-3}\right)$ & $30.2 \pm 12.3$ & $23.7 \pm 5.6$ \\
Circulating neutrophils & & \\
$\left(\times 10^{2} \mathrm{~mm}^{-3}\right)$ & $0.8 \pm 0.3^{\mathrm{a}}$ & $0.5 \pm 0.2^{\mathrm{b}}$ \\
NBT index & $169.2 \pm 48.6^{\mathrm{a}}$ & $88.6 \pm 35.9^{\mathrm{b}}$ \\
ACH50 $\left(\mathrm{U} \mathrm{mL}^{-1}\right)$ & & \\
\hline Values with different letters & within a line are significantly different \\
$(P<0.05)$. & & \\
$n=6 \times 3$. & &
\end{tabular}

The n-3 HUFA-deficient diet produced a significant $(P<0.05)$ increase in both circulating RBC and total $\mathrm{Hb}$. No effect of dietary EFA deficiency was found on haematocrit, $\mathrm{MCH}$ and $\mathrm{MCHC}$ (Table 3). Mean erythrocyte volume (MCV) was significantly lower $(P<0.05)$ in fish fed the NFA diet, compared with fish fed the control diet. Erythrocyte fragility was significantly increased $(P<0.05)$ in fish fed the NFA diet (Table 3). A lack of n-3 HUFA in the diet significantly decreased $(P<0.05)$ circulating lymphocytes and slightly, but not significantly, reduced the number of circulating neutrophils. Moreover, the activity of those cells, measured as the NBT index, was significantly $(P<0.05)$ lower when compared with control fish (Table 3). The EFA-deficient diet induced a significant reduction $(P<0.05)$ in the activity of the serum alternative complement pathway (Table 3).

The EFA-deficient diet produced an accumulation of lipids in the liver of fish (Table 4). Fish fed

Table 4 Main fatty acid composition of the liver of fish fed the experimental diets $(\mathrm{g} / 100 \mathrm{~g}$ of fatty acids)

\begin{tabular}{|c|c|c|}
\hline \multirow[b]{2}{*}{ Fatty acid } & \multicolumn{2}{|l|}{ Diet } \\
\hline & C & NFA \\
\hline $14: 0$ & $3.2 \pm 0.2$ & $2.7 \pm 0.2$ \\
\hline $15: 0$ & $0.1 \pm 0.1$ & $0.2 \pm 0.0$ \\
\hline $16: 0$ & $20.5 \pm 0.3$ & $21.7 \pm 0.3$ \\
\hline $16: 1 n-7$ & $5.0 \pm 0.7^{\mathrm{a}}$ & $2.9 \pm 1.3^{b}$ \\
\hline $17: 0$ & $0.4 \pm 0.0$ & $0.3 \pm 0.0$ \\
\hline $17: 1$ & $0.5 \pm 0.0$ & $0.5 \pm 0.0$ \\
\hline $16: 4 n-3$ & $0.2 \pm 0.0^{\mathrm{a}}$ & $0.0 \pm 0.0^{b}$ \\
\hline 18:0 & $8.00 \pm 0.3$ & $7.7 \pm 0.2$ \\
\hline $18: 1 n-9$ & $25.8 \pm 0.6^{\mathrm{a}}$ & $37.2 \pm 1.4^{b}$ \\
\hline $18: 1 n-7$ & $3.1 \pm 0.1$ & $1.2 \pm 0.2$ \\
\hline $18: 2 n-6$ & $1.5 \pm 0.3^{a}$ & $2.1 \pm 0.2^{b}$ \\
\hline $18: 3 n-3$ & $0.3 \pm 0.1$ & $0.2 \pm 0.0$ \\
\hline $18: 4 n-3$ & $0.6 \pm 0.1^{a}$ & $0.2 \pm 0.0^{b}$ \\
\hline $20: 1 n-9$ & $1.1 \pm 0.8$ & $1.3 \pm 0.1$ \\
\hline $20: 1 n-7$ & $0.5 \pm 0.8$ & $0.3 \pm 0.2$ \\
\hline $20: 4 n-6$ & $1.3 \pm 0.4$ & $0.8 \pm 0.3$ \\
\hline $20: 5 n-3$ & $4.9 \pm 0.3^{a}$ & $2.3 \pm 0.1^{b}$ \\
\hline $22: 1 n-11$ & $0.6 \pm 0.3^{a}$ & $0.2 \pm 0.1^{b}$ \\
\hline $22: 1 n-9$ & $0.4 \pm 0.0^{a}$ & $0.6 \pm 0.2^{b}$ \\
\hline $22: 5 n-6$ & $0.2 \pm 0.1$ & $0.1 \pm 0.1$ \\
\hline $22: 5 n-3$ & $2.4 \pm 0.0^{\mathrm{a}}$ & $0.9 \pm 0.1^{b}$ \\
\hline $22: 6 n-3$ & $10.8 \pm 0.7$ & $6.7 \pm 0.8^{b}$ \\
\hline Saturated & $32.2 \pm 0.6$ & $32.6 \pm 0.3$ \\
\hline Monoenoics & $37.6 \pm 0.9^{a}$ & $46.0 \pm 0.8^{b}$ \\
\hline$\Sigma \mathrm{n}-3$ & $19.8 \pm 1.1^{a}$ & $10.8 \pm 0.8^{b}$ \\
\hline$\Sigma \mathrm{n}-6$ & $3.9 \pm 0.3$ & $3.8 \pm 0.3$ \\
\hline$\Sigma \mathrm{n}-9$ & $28.3 \pm 0.7^{\mathrm{a}}$ & $40.3 \pm 1.4^{b}$ \\
\hline n-3 HUFA & $18.8 \pm 1.1^{\mathrm{a}}$ & $10.4 \pm 0.8^{b}$ \\
\hline EPA/ARA & $0.5 \pm 0.0^{\mathrm{a}}$ & $0.2 \pm 0.0^{b}$ \\
\hline
\end{tabular}




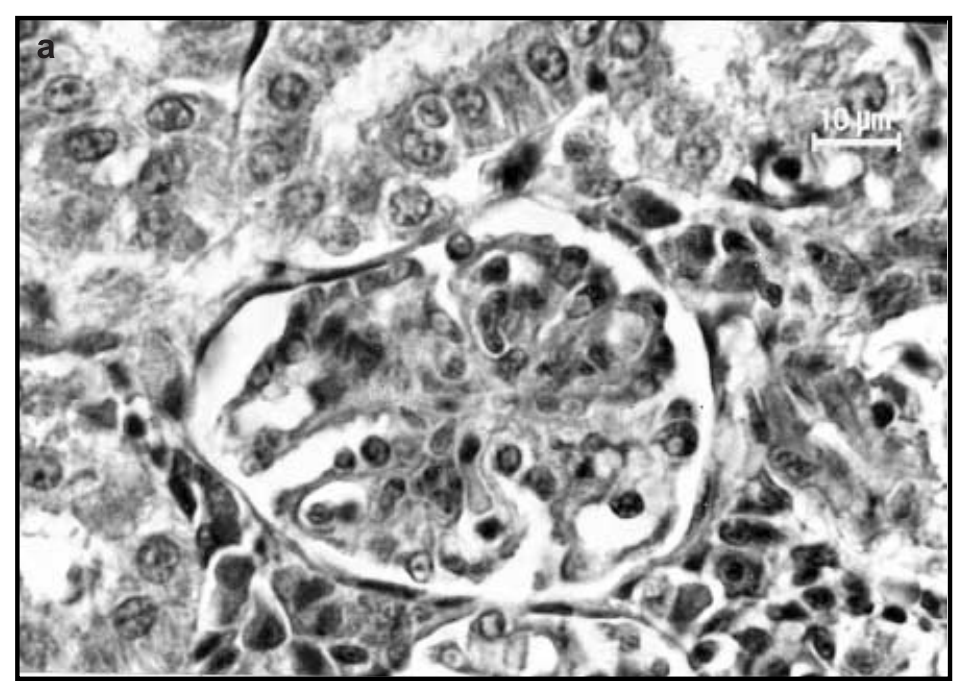

Figure 1 (a) Semithin section of renal glomeruli from fish fed control diet. Bowman's space is present and no dilated capillaries are seen $(\mathrm{H} \& \mathrm{E})$. (b) Semithin section of renal glomeruli from fish fed n-3 HUFAdeficient diet. Note occluded Bowman's space and extremely dilated capillaries (arrows). Slight mesangial cell proliferation is also observed $(*)(\mathrm{H} \& \mathrm{E})$.

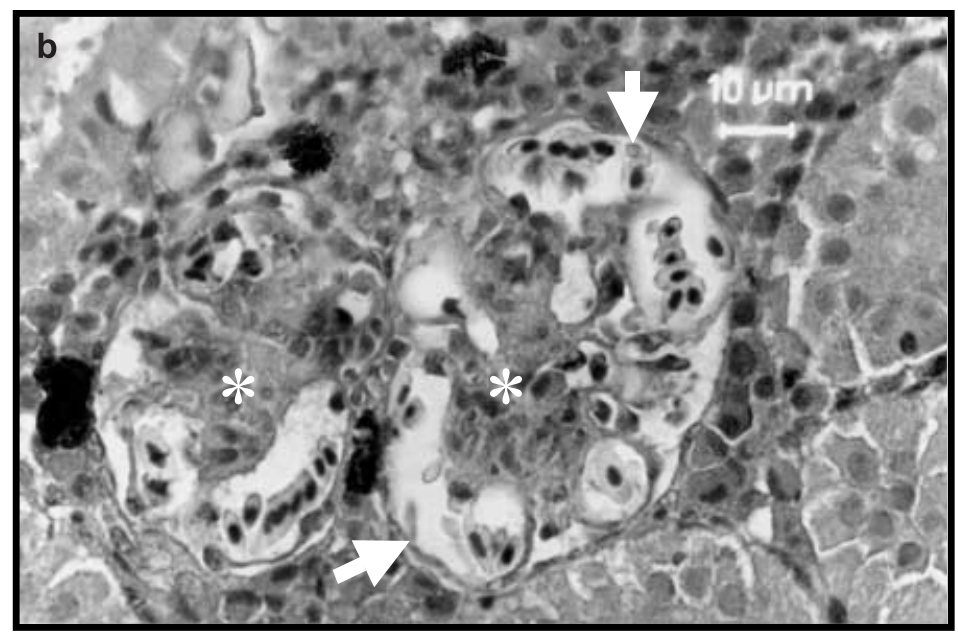

the EFA-deficient diet showed a different fatty acid profile from that of fish fed the control diet. The most important differences were an increased level of oleic acid (18:1n-9) and a decreased level of n-3 HUFA, mainly due to a decrease in docosahexaenoic acid (DHA) and eicosapentaenoic acid (EPA) (Table 4).

Control fish showed glomeruli with a welldefined Bowman's space and no dilated capillaries (Fig. 1a). No alterations were found in renal tubes from those fish fed diet $\mathrm{C}$.

However, up to $88 \%$ of fish fed the NFA diet showed changes in at least $50 \%$ of the renal glomeruli (Fig. 1b). The glomeruli of these fish showed two main alterations: an extreme dilation of glomerular capillaries and an occlusion of Bowman's capsule, which almost disappeared (Fig. 1b). A slight mesangial proliferation was observed
(Fig. 1b). A diffuse thickening of both the capillary walls and the basement membrane was also observed with PAS staining, with no podocyte proliferation.

Renal tubule degeneration was also observed in those fish with glomerular alterations. Renal tubes showed epithelial cell desquamation from the basement membrane with subsequent cloudy swelling degeneration (Fig. 2a,b).

\section{Discussion}

Fish fed a deficient diet in the present study showed the previously described signs of n-3 HUFA deficiency (Watanabe 1982), including decreased growth and increased hepatic lipid content. In addition, EFA dietary deficiency significantly altered fatty acid composition of the liver, mainly 

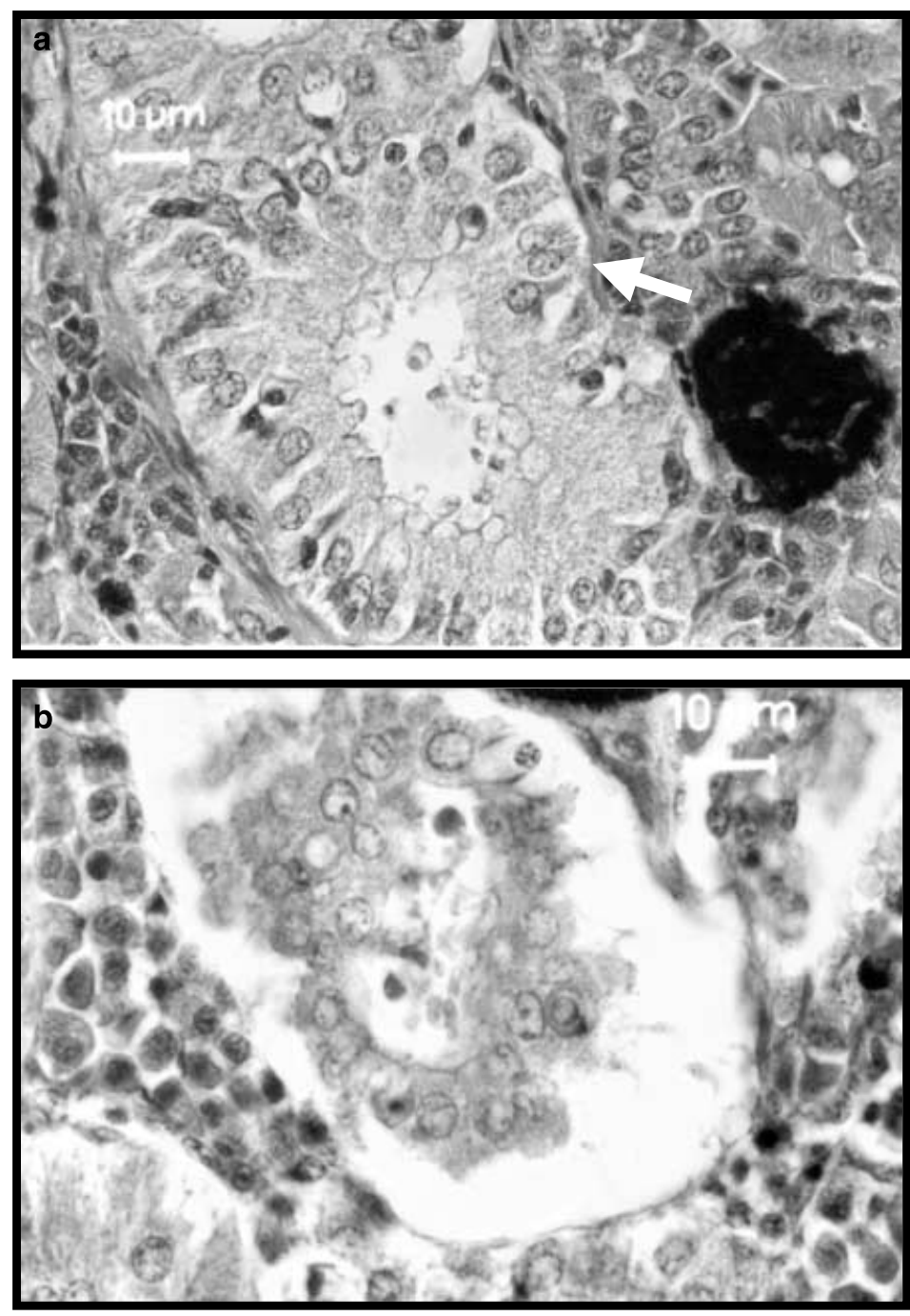

Figure 2 Semithin section of renal tubules from fish fed a n-3 HUFA-deficient diet. (a) Tubular epithelial cells desquamated from the basement membrane (arrow) and (b) cloudy swelling degeneration (H \& E).

increasing oleic acid and decreasing n-3 HUFA content. Fish fed the NFA diet also showed steatosis of the liver (Montero, Socorro \& Caballero, unpublished data), another sign of EFA deficiency and previously described for this species under similar experimental conditions (Montero et al. 2001).

Fish fed an n-3 HUFA-deficient diet in the present study showed increased haemoglobin and RBC count, mainly due to a decrease in erythrocyte volume that enhances oxygen delivery (Lay \& Baldwin 1999), as a consequence of the possible increased oxygen consumption due to high saturated fatty acid levels in diet. The inclusion of coconut oil (rich in saturated fatty acids) in the diet of Adriatic sturgeon, Acipenser naccarii Bonaparte, increased oxygen consumption when compared with fish fed a fish oil based diet (McKenzie,
Piraccini, Steffensen, Bolis, Bronzi \& Taylor 1995). Gilthead sea bream juveniles fed a n-3 HUFAdeficient diet have been shown to have different post-stress plasma cortisol levels compared with those on a non-deficient diet (Montero et al. 1998) and the inclusion of linseed oil in gilthead sea bream diets also alters the time-course of plasma cortisol changes after stress (Montero, Kalinowski, Obach, Robaina, Tort, Caballero \& Izquierdo 2003). EFAs have been shown to influence physiological responses to different stressors in cultured fish. DHA has been shown to be essential in the stress resistance of marine fish larvae (Kanazawa 1997).

Dietary fatty acid composition also affects the lipid composition of erythrocytes and cell membrane function is greatly affected by unsaturation 
(Leray, Nonnotte \& Nonnotte 1986). The erythrocytes of fish fed a n-3 HUFA-deficient diet showed higher fragility (measured as spontaneous haemolysis) than those of fish fed a fish oil based diet. This is in agreement with the results obtained by Salte, Thomassen \& Wold (1988) who described high osmotic resistant erythrocytes in diseased Atlantic salmon, Salmo salar L., fed increasing levels of n-3 PUFA. Erdal, Evensen, Kaurstad, Lillehaug, Solbakken \& Thorud (1991) also found a positive correlation between cell membrane strength and an increase of dietary n-3 HUFA. Similar results have been obtained by Kiron, Takeuchi \& Watanabe (1994) who found that low levels of both n-3 and n-6 in the erythrocyte membranes of rainbow trout fed a saturated fatty acid diet resulted in their being liable to osmotic changes.

Dietary fatty acid imbalance also affects mechanisms of the immune system of cultured fish (reviewed by Blazer 1992; Lall \& Olivier 1993; Waagboe 1994; Fletcher 1997; Lall 2000) but little is known about the role of specific fatty acids in the different processes of the immune system. Dietary lipids can modulate cellular responses by influencing the physical properties of membranes, the membrane-associated enzymes, receptor sites and synthesis of immunomodulator eicosanoids.

In the present study, a dietary deficiency of $n-3$ HUFA affected cellular immunity, reducing both neutrophil activity, measured as the NBT index, and the number of circulating lymphocytes. Sheldon \& Blazer (1991) found a positive correlation between dietary n-3 HUFA and bactericidal activity of channel catfish macrophages. The natural killer cell-like activity of rainbow trout leucocytes was also enhanced by dietary n-3 HUFA (Kiron, Gunji, Okamoto, Satoh, Ikeda \& Watanabe 1993). Resistance to infection of Atlantic salmon was superior in fish fed a high ratio n-3/n-6 PUFA diet than fish fed a low ratio n-3/n-6 diet (Thompson, Tatner \& Henderson 1996). Ashton et al. (1994) found that head kidney supernatants derived from rainbow trout fed a diet enriched with n-3 fatty acid had greater migration stimulating ability when compared with fish fed an n-6 fatty acid enriched diet.

Dietary fatty acid composition also affects the humoural immune system. Waagboe, Hemre, Holm \& Lie (1995) found a negative correlation between complement activity and monoenes present in serum. A depletion of alternative comple- ment pathway activity has been described for gilthead sea bream fed a n-3 HUFA-deficient diet (Montero et al. 1998). In the present study, EFA dietary deficiency also affected serum complement activity, corresponding with the higher amount of monoenes in the diet.

The role of $n-3$ HUFAs in the amelioration of renal damage has been widely studied in human health (Donadio, Bergstralh, Offord, Spencer \& Holley 1994; Hogg \& Waldo 1996; Donadio, Dart, Grande, Bergstralh \& Spencer 1999), but little is known about the specific role of these fatty acids in the modulation of the consequences of renal injury in fish. Glomerular proliferative change with proliferation of the mesangial cells, dilatation of blood capillaries and thickening of the walls, clogging of the space between glomeruli and Bowman's capsule or thickening of the basal lamina have been reported as anomalous conditions of the glomeruli (Hibiya 1982). These alterations can be found in different nephropathies described in fish such as diffuse glomerulonephritis in white perch, Morone americana (Gmelin), from heavily polluted water (Ferguson, Moccia \& Down 1982), proliferative glomerulonephritis of selenium-exposed green sunfish, Lepomis cyanellus Rafinesque (Sorensen, Harlan \& Bell 1982), or immune complex-mediated glomerulonephritis in rainbow trout (Sami, Fischer-Scherl, Hoffmann \& Pfeil-Putzien 1992).

The renal changes found in the present study include some of the above signs of renal injury, but were not sufficient to determine the kind of glomerulonephritis associated with n-3 HUFA dietary deficiencies in gilthead sea bream juveniles. Despite the lack of information regarding the effect of dietary lipids in fish glomerulonephritis, it has been shown recently in higher vertebrates that n-3 PUFAs are rapidly and effectively incorporated into the renal tissue of rats and that DHA significantly inhibits the proliferation of cultured mesangial cells in vitro by reducing their uptake of ${ }^{3} \mathrm{H}$-thymidine (Grande, Walker, Holub, Warner, Keller, Haugen, Dodanio \& Dousa 2000).

The depletion of the alternative complement pathway activity found in fish fed the NFA diet could be acting as an indirect precursor of glomerular injury, as glomerulonephritis associated with hypocomplementaemia has been described in humans (Kurihara, Saito, Sato, Chiba, Saito, Soma \& Ito 1998). The complement system plays a critical role in the clearance of immune complexes by leading to the covalent attachment of $\mathrm{C} 3 \mathrm{~b}$ and $\mathrm{C} 4 \mathrm{~b}$ 
factors to the complex facilitating their solubilization (Lambris \& Holers 2000) and binding to the CR1 receptors on erythrocytes and phagocytes, directing the immune complexes to the reticuloendothelial system, where they are removed from circulation (Song, Sarrias \& Lambris 2000). If the complement system is depleted, some immunecomplexes may have been deposited in glomeruli as they could not be removed from the circulation. Deposition of immune-complexes in the renal glomeruli has been related to vasculitis and glomerulonephritis (Song et al. 2000). No pathogens were isolated in the experimental fish but a chronic deposition of immune complexes in the renal glomeruli cannot be ruled out.

Some studies have shown beneficial effects of $n-3$ fatty acids in human chronic glomerulonephritis (Malyszko, Malyszko, Pawlak \& Mysliwiec 1996) and nephropathy (Barcelli, Weiss, Beach, Motz \& Thompson 1990; Wheeler, Nair, Persaud, Jeremy, Chappell, Varghese \& Moorhead 1991; D’Amico \& Gentile 1993) due to the role of these fatty acids in the regulation of eicosanoid production. A reduction of the dietary EPA/arachidonic acid (ARA) ratio could enhance the production of PGE2 and TXA2 derived from ARA, which has been shown to produce intense vasoconstriction and mesangial cell contraction (Sakr \& Dunham 1982) causing renal injury (Wheeler et al. 1991). EPA is a competitive substrate for tromboxane A3 with lesser vasoconstricting properties (Fischer \& Weber 1983) and is also a substrate for prostacyclin (PGI3) (Fischer \& Weber 1984). Dietary imbalance of fatty acid precursors of eicosanoids could indirectly affect renal glomerular integrity and glomerulonephritis mediated directly by a deficiency of dietary n-3 HUFA cannot be ruled out.

In conclusion, dietary n-3 HUFA deficiency produces alterations in the oxygen-carrying capacity of gilthead sea bream blood, immunosuppresion of both cellular and humoural systems, and renal injury, including renal tube degeneration and systemic glomerulonephritis. Further experiments are required to elucidate the role of the dietary fatty acid on the glomeruli of fish and the origin of the glomerulonephritis described in the present study.

\section{Acknowledgements}

The authors would like to thank Dr O. Sunyer from the School of Veterinary Medicine, University of Pennsylvania, PA, USA, and Dr L.A. Romano from the Centro de Biopatología Acuática, University of Bar-Ilan, Argentina, for their valuable comments and recommendations.

\section{References}

Ashton I., Clemens K., Barrow S.E., Secombes C.J. \& Rowley A.F. (1994) Effects of dietary fatty acids on eicosanoid-generating capacity, fatty acid composition and chemotactic activity of rainbow trout (Oncorhynchus mykiss) leucocytes. Biochimica et Biophysica Acta 1214, 253-262.

Barcelli U.O., Weiss M., Beach D., Motz A. \& Thompson B. (1990) High linoleic acid diets ameliorate diabetic nephropathy in rats. American Journal of Kidney Diseases 16, 244-251.

Blazer V.S. (1992) Nutrition and disease resistance in fish. Annual Review of Fish Diseases 1, 309-323.

Caballero M.J., Obach A., Rosenlund G., Montero D., Gisvold M. \& Izquierdo M.S. (2002) Impact of different dietary lipid sources on growth, lipid digestibility, tissue fatty acid composition and histology of rainbow trout, Oncorhynchus mykiss. Aquaculture 214, 253-271.

Caballero M.J., Izquierdo M.S., Kjorsvik E., Montero D., Socorro J., Fernández A. \& Rosenlund G. (2003) Morphological aspects of the intestinal cells from gilthead seabream (Sparus aurata) fed diets containing different lipid sources. Aquaculture 225, 325-340.

Chandrasekar B. \& Fernandes G. (1994) Decreased proinflammatory cytokines and increased antioxidant enzyme gene expression by w-3 lipids in murine lupus nephritis. Biochemical and Biophysical Research Communications 200, 893-898.

Christie W.W. (1982) Lipid Analysis. Pergamon Press, Oxford.

Cowey C.W., Adron J.W., Murray J., Youngson A. \& Knox D. (1981) Tissue distribution, uptake and requirement for alphatocopherol of rainbow trout (Salmo gairdneri) fed diets with a minimal content of unsaturated fatty acids. Journal of Nutrition 51, 443-451.

D’Amico G. \& Gentile M.G. (1993) Influence of diet on lipid abnormalities in human renal disease. American Journal of Kidney Diseases 22, 151-157.

Donadio J.V., Bergstralh E.J., Offord K.P., Spencer D.C. \& Holley K.E. (1994) A controlled trial of fish oil in IgA nephropathy. New England Journal of Medicine 331, 1194-1199.

Donadio J.V., Dart R.A., Grande J.P., Bergstralh E.J. \& Spencer D.C. (1999) The long-term outcome of patients with IgA nephropathy treated with fish oil in a controlled trial. Journal of the American Society of Nephrology 10, 1772-1777.

Draper H.H. \& Csallany A.S. (1969) A simplified hemolysis test for vitamin E deficiency. Journal of Nutrition 98, 390-394.

Erdal J.I., Evensen O., Kaurstad O.K., Lillehaug A., Solbakken R. \& Thorud K. (1991) Relationship between diet and immune response in Atlantic salmon (Salmo salar, L.) after feeding various levels of ascorbic acid and omega- 3 fatty acids. Aquaculture 98, 363-379. 
Ferguson H.W., Moccia R.D. \& Down N.E. (1982) An epizootic of diffuse glomerulonephritis in white perch (Roccus americanus) from a heavily polluted industrial basin in Lake Ontario. Veterinary Pathology 19, 638-645.

Fischer S. \& Weber P.C. (1983) Thromboxane A3 (TXA3) is formed in human platelets after dietary eicosapentaenoic acid (C20:5 omega 3). Biochemical and Biophysical Research Communications 116, 1091-1099.

Fischer S. \& Weber P.C. (1984) Prostaglandin I3 is formed in vivo in man after dietary eicosapentaenoic acid. Nature 307, $165-168$.

Fletcher T.C. (1997) Dietary effects on stress and health. In: Fish Stress and Health in Aquaculture (ed. by G.K. Iwama, A.D. Pickering, J.P. Sumpter \& C.B. Schreck), pp. 223-246. Cambridge University Press, Cambridge.

Folch J., Lees M. \& Sloane-Stanley G.H. (1957) A simple method for the isolation and purification of total lipids from animal tissues. Journal of Biological Chemistry 226, 497-509.

Goldstein D.J., Wheeler D.C., Sandstrom D.J., Kawachi H. \& Salant D.J. (1995) Fish oil ameliorates renal injury and hyperlipidemia in the Milan normotensive rat model of focal glomerulosclerosis. Journal of the American Society of Nephrology 6, 1468-1475.

Grande J.P., Walker H.J., Holub B.J., Warner G.M., Keller D.M., Haugen J.D., Dodanio V. \& Dousa T.P. (2000) Suppressive effects of fish oil on mesangial cell proliferation in vitro and in vivo. Kidney International 57, 1027-1040.

Hibiya T. (1982) An Atlas of Fish Histology. Normal and Pathological Features. Kodansha Ltd, Tokyo, Japan.

Hogg R.J. \& Waldo B. (1996) Advances in treatment: immunoglobulin A nephropathy. Seminars in Nephrology 16, 511-516.

Izquierdo M.S., Watanabe T., Takeuchi T., Arakawa T. \& Kitajima C. (1990) Optimum EFA levels in Artemia to meet the EFA requirements of red sea bream (Pagrus major). In: The Current Status of Fish Nutrition in Aquaculture (ed. by M. Takeda \& T. Watanabe), pp. 221-232. Tokyo University of Fisheries, Tokyo.

Kanazawa A. (1997) Effects of docosahexaenoic acid and phospholipids on stress tolerance of fish. Aquaculture 155, 129-134.

Kiron V., Gunji A., Okamoto N., Satoh S., Ikeda Y. \& Watanabe T. (1993) Dietary nutrient dependent variations on natural-killer activity of leucocytes of rainbow trout. Gyobyo Kenkyu 28, 71-76.

Kiron V., Takeuchi T. \& Watanabe T. (1994) The osmotic fragility of erythrocytes in rainbow trout under different dietary fatty acid status. Fisheries Science 60, 93-95.

Kiron V., Fukuda H., Takeuchi T. \& Watanabe T. (1995) Essential fatty acid nutrition and defence mechanisms in rainbow trout Oncorhynchus mykiss. Comparative Biochemistry and Physiology 111A, 361-367.

Klontz G.W. (1994) Fish hematology. In: Techniques in Fish Immunology, Vol. III (ed. by J.S. Stolen, T.C. Fletcher, A.F. Rowley, J.T. Zelikoff, S.L. Kaattari \& S.A. Smith), pp. 121 131. SOS Publications, Fair Haven.
Kurihara I., Saito T., Sato H., Chiba J., Saito J., Soma J. \& Ito S. (1998) Successful treatment with steroid pulse therapy in a case of immunotactoid glomerulopathy with hypocomplementemia. American Journey of Kidney Diseases 32, E4.

Lall S.P. (2000) Nutrition and health of fish. In: Avances en Nutrición Acuicola V. Memorias del V Simposium Internacional de Nutrición Acuicola (ed. by L.E. Cruz-Suárez, D. RicqueMarie, M. Tapia-Salazar, M.A. Olvera-Novoa \& R. CiveraCerecedo), pp. 13-23. Mérida, Yucatán, México.

Lall S.P. \& Olivier G. (1993) Role of micronutrients in immune response and disease resistance in fish. In: Fish Nutrition in Practice. Institut National de la Recherche Agronomic (INRA) eds, Paris. Les Colloques 61, 101-108.

Lambris J.D. \& Holers V.M. (2000) Therapeutic Interventions in the Complement System. Humana Press, Totowa, NJ.

Lay P. \& Baldwin J. (1999) What determines the size of teleost erythrocytes? Correlations with oxygen transport and nuclear volume. Fish Physiology and Biochemistry 20, 31-35.

Leray C., Nonnotte G. \& Nonnotte L. (1986) The effect of dietary lipids on the trout erythrocyte membrane. Fish Physiology and Biochemistry 1, 27-35.

McKenzie D.J., Piraccini G., Steffensen J.F., Bolis C.L., Bronzi P. \& Taylor E.W. (1995) Effects of diet on spontaneous locomotor activity and oxygen consumption in Adriatic sturgeon (Acipenser naccarii). Fish Physiology and Biochemistry 14, 341-355.

Malyszko J.S., Malyszko J., Pawlak K. \& Mysliwiec M. (1996) Effect of treating glomerulonephritis with omega 3 fatty acids for selected parameters of hemostasis, blood platelet function and lipid metabolism. Przeglad lekarski 53, 600-603.

Martoja R. \& Martoja-Pierson R.R. (1970) Técnicas de Histología Animal. Toray-Masson, S.A., Barcelona.

Montero D., Tort L., Izquierdo M.S., Socorro J., Robaina L., Vergara J.M. \& Fernández-Palacios H. (1996) Effect of $\alpha$-tocopherol and n-3 HUFA deficient diets on blood cells, selected immune parameters and proximate body composition of gilthead seabream (Sparus aurata). In: Modulators of Immune Response. The Evolutionary Trail (ed. by J.S. Stolen, T.C. Fletcher, C.J. Bayne, C.J. Secombes, J.L. Zelikoff, L. Twerdok \& D.P. Anderson), pp. 251-266. SOS Publications, Fair Haven.

Montero D., Tort L., Izquierdo M.S., Robaina L. \& Vergara J.M. (1998) Depletion of serum alternative complement pathway activity in gilthead seabream caused by alpha-tocopherol and n-3 HUFA dietary deficiencies. Fish Physiology and Biochemistry 18, 399-407.

Montero D., Blazer V.S., Socorro J., Izquierdo M.S. \& Tort L. (1999) Dietary and culture influences on macrophage aggregate parameters in gilthead seabream (Sparus aurata) juveniles. Aquaculture 179, 523-534.

Montero D., Robaina L.E., Socorro J., Vergara J.M., Tort L. \& Izquierdo M.S. (2001) Alteration of liver and muscle fatty acid composition in gilthead seabream (Sparus aurata) juveniles held at high stocking density and fed an essential fatty acid deficient diet. Fish Physiology and Biochemistry 24, 63-72.

Montero D., Kalinowski T., Obach A., Robaina L., Tort L., Caballero M.J. \& Izquierdo M.S. (2003) Vegetable lipid 
sources for gilthead seabream (Sparus aurata): effects on fish health. Aquaculture 225, 353-370.

Mourente G. \& Tocher D. (1993) Incorporation and metabolism of ${ }^{14} \mathrm{C}$-labelled polyunsaturated fatty acids in juvenile sea bream Sparus aurata L. in vivo. Fish Physiology and Biochemistry 10, 443-453.

Olsen R.E., Myklebust R., Kaino T. \& Ringø E. (1999) Lipid digestibility and ultrastuctural changes in the enterocytes of Arctic charr (Salvelinus alpinus L.) fed linseed oil and soybean lecithin. Fish Physiology and Biochemistry 21, 35-44.

Robaina L., Izquierdo M.S., Moyano F.J., Socorro J., Vergara J.M. \& Montero D. (1998) Increase of the dietary n $3 / \mathrm{n} 6$ fatty acids ratio and addition of phosphorus improves liver histology alterations induced by feeding diets containing soybean meal in gilthead seabream (Sparus aurata). Aquaculture 161, 281-293.

Rowley A.F., Knight J., Lloyd-Evans P., Holland J.W. \& Vickers P.J. (1995) Eicosanoids and their role in immune modulation in fish. A brief overview. Fish and Shellfish Immunology 5, 549567.

Sakr H.M. \& Dunham E.W. (1982) Mechanism of arachidonic acid-induced vasoconstriction in the intact rat kidney: possible involvement of tromboxane A2. Journal of Pharmacology and Experimental Therapeutics 221, 614-622.

Salte R., Thomassen M.S. \& Wold K. (1988) Do high levels of dietary polyunsaturated fatty acids (EPA/DHA) prevent diseases associated with membrane degeneration in farmed Atlantic salmon at low water temperatures? Bulletin of the European Association of Fish Pathologists 8, 63-65.

Sami S., Fischer-Scherl R., Hoffmann W. \& Pfeil-Putzien C. (1992) Immune complex-mediated glomerulonephritis associated with bacterial kidney disease in the rainbow trout (Oncorhynchus mykiss). Veterinary Pathology 29, 169-174.

Sheldon W.H. \& Blazer V.S. (1991) Influence of dietary lipid and temperature on bactericidal activity of channel catfish macrophages. Journal of Aquatic Animal Health 3, 87-93.

Siwicki A., Anderson D.P. \& Antychowitz J. (1993) Nonspecific defence mechanisms assay in fish I. Phagocytic index, adherence and phagocytic ability of neutrophils (NBT test) and myeloperoxidase activity test. In: Fish Disease Diagnosis and Prevention Methods. FAO (eds). Technical Report Project GCP/INT/526/JPN. pp. 95-103.
Sokal R.R. \& Rohlf S.J. (1995) Biometry. The Principles and Practice of Statistics in Biological Research, 3rd edn. W.H. Freeman and Co., New York.

Song W.C., Sarrias M.R. \& Lambris J.D. (2000) Complement and innate immunity. Immunopharmacology 49, 187-198.

Sorensen E.M., Harlan C.W. \& Bell J.S. (1982) Renal changes in selenium-exposed fish. American Journal of Forensic Medicine and Pathology 3, 123-129.

Sumpter J.P. (1997) The endocrinology of stress. In: Fish Stress and Health in Aquaculture (ed. by G.K. Iwama, A.D. Pickering, J.P. Sumpter \& C.B. Schreck), pp. 95-118. Cambridge University Press, Cambridge.

Sunyer J.O. \& Tort L. (1995) Natural hemolytic and bactericidal activities of seabream Sparus aurata serum are affected by the alternative complement pathway. Veterinary Immunology and Immunopathology 45, 333-345.

Thompson K.D., Tatner M.F. \& Henderson R.J. (1996) Effects of dietary $(n-3)$ and $(n-6)$ polyunsaturated fatty acid ratio on the immune response of Atlantic salmon (Salmo salar L.). Aquaculture Nutrition 2, 21-31.

Waagboe R. (1994) The impact of nutritional factors on the immune system in Atlantic salmon, Salmo salar L.: a review. Aquaculture and Fisheries Management 25, 175-197.

Waagboe R., Hemre J., Holm C.H.R. \& Lie O. (1995) Tissue fatty acid composition, haematology and immunity in adult cod, Gadus morhua L., fed three dietary lipid sources. Journal of Fish Diseases 18, 615-622.

Watanabe T. (1982) Lipid nutrition in fish. Comparative Biochemistry and Physiology 73, 3-15.

Wheeler D.C., Nair D.R., Persaud J.W., Jeremy J.Y., Chappell M.E., Varghese Z. \& Moorhead J.F. (1991) Effects of dietary fatty acids in an animal model of focal glomerulosclerosis. Kidney International 39, 930-937.

Wilson R.P., Bowser P.R. \& Poe W.E. (1984) Dietary vitamin E requirement of fingerling channel catfish. Journal of Nutrition 114, 2053-2058.

Received: 7 July 2003

Revision received: 19 January 2004

Accepted: 11 March 2004 